\author{
Dorota Kornas-Biela* \\ ORCID: 0000-0001-6002-1901 \\ Lublin, Polska
}

\title{
„Zmartwychwstanie Rzymu” Chiary Lubich. Refleksja w świetle psychopedagogiki specjalnej
}

\section{Chiara Lubich's "Resurrection of Rome". Reflections in Light of Special Psychopedagogy}

Summary: The article undertakes a reflection on the significance of Chiara Lubich's text „The Resurrection of Rome” for special needs psychopedagogy. First, it responds to the question of the subject of this short ,philosophical-theological thesis", i.e., what is the state of the contemporary human person, who observing ,contemporary Rome" full of dirt, vanity and sin not only surrounding him or herself, but also within, simultaneously deciphers his or her destiny as being resurrection. Created in the likeness of God, the human person is free and called to free and joyful ,gaining of Heaven" and to relationship with God. In the contemporary world, disability continues to be received as „bad" and a deprivation of the most important values; it draws negative social attitudes, and so it is important to offer a key to change this destructive attitude toward others. The second section of the article is devoted to an analysis of the suggestions which Ch. Lubich included in the text ,The Resurrection of Rome", and which may be used in the process of changing attitudes

* Dr hab. Dorota Kornas-Biela, prof. KUL, jest kierownikiem Katedry Psychopedagogiki w Instytucie Pedagogiki Katolickiego Uniwersytetu Lubelskiego Jana Pawła II. Adres: Instytut Pedagogiki KUL, al. Racławickie 14, 20-950 Lublin; e-mail: dorota@biela.pl. 
towards people with disability. These suggestions correspond to the assumptions of Christian personalism in special needs education.

Keywords: Chiara Lubich; Focolare; the spirituality of unity; special needs psychopedagogy; disabled individuals; Christian personalism.

Streszczenie: W artykule została podjęta refleksja nad znaczeniem tekstu Chiary Lubich „Zmartwychwstanie Rzymu” dla psychopedagogiki specjalnej. Najpierw starano się odpowiedzieć na pytanie, co jest przedmiotem tego krótkiego „traktatu filozoficzno-teologicznego", jaka jest kondycja współczesnego człowieka, który widzi nie tylko wokół siebie, ale też w sobie „współczesny Rzym” pełen brudu, marności i grzechu, a jednocześnie odczytuje swoje przeznaczenie do zmartwychwstania. Stworzony na podobieństwo Boga, jest wolny i powołany do wolnego i radosnego „zdobywania Nieba”, do więzi z Bogiem. We współczesnym świecie niepełnosprawność jest nadal odbierana jako zło i pozbawienie najważniejszych wartości, budzi negatywne postawy społeczne, dlatego ważne jest podanie klucza do zmiany tego destrukcyjnego odnoszenia się do drugich. Druga część artykułu została poświęcona analizie podpowiedzi, które Lubich zawarła w tekście „Zmartwychwstanie Rzymu", a które mogą być wykorzystane w procesie zmiany postaw wobec osób z niepełnosprawnością. Korespondują one z założeniami personalizmu chrześcijańskiego w pedagogice specjalnej.

Slowa kluczowe: Chiara Lubich; Focolare; duchowość jedności; psychopedagogika specjalna; osoba z niepełnosprawnością; personalizm chrześcijański.

Chiara Lubich (22.01.1920-14.03.2008), założycielka światowego i międzyreligijnego ruchu w Kościele katolickim Focolare („Dzieło Maryi”), obecnego w ponad 180 krajach świata i zrzeszającego kilka milionów ludzi o różnym stopniu zaangażowania, jest autorką ogromnej liczby tekstów, m.in. publikowanych przez kilkadziesiąt lat co miesiąc „Słów Życia”, tłumaczonych na wiele języków świata. Szczególnym wyrazem podjęcia wyzwania Chiary Lubich do jedności oraz realizacji słów św. Jana Pawła II: „Należy czynić Kościół domem i szkołą komunii” jest publikowanie przez Fundację Mariapoli kwartalnika Jedność i Charyzmaty, który na wzór włoskiego czasopisma Unità e Carismi wydawanego w wielu językach służy

\footnotetext{
${ }^{1}$ Jan Paweł II, Novo millennio ineunte, nr 43 (Poznań: Pallotinum, 2001).
} 
sprawie powszechnego braterstwa, jedności i pokoju. W języku polskim ukazało się już kilkanaście pozycji z tekstami Chiary Lubich, dwie pozycje naukowe na temat jej życia i Ruchu Focolare ${ }^{2}$ oraz inicjatyw, które przy nim powstały, jak np. ekonomia komunii dóbr ${ }^{3}$, kilka książek o niej i Ruchu Focolari ${ }^{4}$ oraz publikacje naukowe ${ }^{5}$. Duchowość Chiary Lubich, zwłaszcza z punktu widzenia pedagogicznego, omawia w swoich publikacjach Mariola Kozubek $^{6}$. Próbę odniesienia tej duchowości do relacji matka-dziecko prenatalne, a tym samym zastosowania paradygmatu jedności na terenie psychopedagogiki prenatalnej, podjęła Dorota Kornas-Biela ${ }^{7}$.

${ }^{2}$ Lucia Abignente, Przeszłość i teraźniejszossć - historia jedności. Studium o duchowości Ruchu Focolari (Lublin: Towarzystwo Naukowe KUL JPII, 2010); Mirosław Szewieczek, Bijące serce jedności (Bielsko-Biała: Wydawnictwo AKANT, 2003).

${ }^{3}$ Stanisław Grochmal, Paradygmat jedności w kontekście zarzadzania organizacjami (Rzeszów: Wydawnictwo Uniwersytetu Rzeszowskiego, 2013). Stanisław Grochmal jest również autorem artykułów omawiających ekonomiczne, społeczne, kulturowe i duchowe aspekty ekonomii komunii, które jednocześnie wskazują na jej walory wychowawcze, zarówno dla tych, którzy dzielą się wypracowanymi dobrami, jak i dla tych, którzy są ich odbiorcami.

${ }^{4} \mathrm{~Np}$. Armando Torno, Chiara Lubich. Życie i dzieło (Poznań: Księgarnia św. Wojciecha, 2012); Przygoda jedności: z założycielka Ruchu Focolari rozmawia Franka Zambonini (Kraków: WAM, 1995).

${ }^{5}$ Lucia Abignente, Dorota Kornas-Biela, Mariola Teresa Kozubek, „Pedagogiczne inspiracje Ruchu Focolari. W kierunku pedagogiki jedności”, w: Wychowanie chrześcijańskie. Między tradycją a współczesnościa, red. Alina Rynio (Lublin: Wydawnictwo. KUL, 2007), 1006-1026; Katarzyna Olbrycht, „Co może odnaleźć pedagog w zbiorze tekstów «Charyzmat jedności» Chiary Lubich”, Nowe Miasto 2-3 (2008): 168.

${ }^{6} \mathrm{~Np}$. Mariola Teresa Kozubek, ,Wychowanie do wiary w rodzinie - propozycja duchowości jedności”, Homo Dei 1 (2014): 23-36; Mariola Teresa Kozubek, ,Środowisko wychowawcze rodziny i Ruchu Focolari w doświadczeniu choroby bł. Chiary Luce Badano (1971-1990)", w: Cierpienie - tajemnica i wyzwanie, red. Antoni Bartoszek (Katowice: Emanuel, 2014), 142-160; Mariola Teresa Kozubek, ,Wspólnota i jedność w wybranych obszarach życia społecznego - doświadczenie Ruchu Focolari”, Paedagogia Christiana 2/36 (2015): 79-108; Mariola Teresa Kozubek, „Wychowanie do przebaczenia w pedagogii jedności”, Paedagogia Christiana 2/38 (2016): 107-126; Mariola Teresa Kozubek, „Wspólnota dzieci i młodzieży Ruchu Focolari miejscem kształtowania umiejętności pokonywania trudności”, Roczniki Pedagogiczne 3 (2018): 57-73; Mariola Teresa Kozubek, Stanisław Grochmal, „Rodzina wspólnotą miłości w świetle pedagogii jedności Ruchu Focolari”, w: Wokół rodziny. Wychowanie, kultura, społeczeństwo, red. Andrzej Garbarz, Grzegorz Grzybek (Rzeszów: Wydawnictwo i Drukarnia Diecezji Rzeszowskiej, 2011), 255-273.

7 Dorota Kornas-Biela, „The Paradigm of Unity in Prenatal Education and Pedagogy”, Journal for Perspectives of Economic Political and Social Integration 1-2/19 (2014): 193-206, DOI: $10.2478 / \mathrm{v} 10241-012-0017-3$. 
Jedną z publikacji Chiary Lubich, przykuwającą szczególną uwagę osób zajmujących się jej spuścizną, jest „Zmartwychwstanie Rzymu”. Jest to krótki tekst powstały jako pokłosie jej doświadczeń mistycznych zwanych „Paradiso" w 1949 r. ${ }^{8}$, a konkretnie 29 października, po powrocie do Rzymu z Fiera di Primiero (region Trydentu). Lubich dostrzegła kontrast między pięknem, czystością, majestatem przyrody gór a realiami rzymskiego życia i jednocześnie poczuła wezwanie, ,aby daru Boga nie uważać za utopię" i patrzeć na świat bez zwątpienia w podarowany mu Ideał ${ }^{9}$.

$\mathrm{Na}$ temat tekstu „Zmartwychwstanie Rzymu” opublikowano już kilka pozycji poza obszarem języka polskiego. Stał się również podstawą refleksji m.in. grupy kilkudziesięciu naukowców z Polski i Włoch, którzy zebrali się na Międzynarodowym Sympozjum Interdyscyplinarnym „Doświadczenie «Zmartwychwstania Rzymu». Perspektywa filozoficzno-społeczna wobec współczesnego kryzysu kultury", zorganizowanym w Centrum Ruchu Focolare w Polsce (Wilga-Trzcianka, 15-16.06.2017 r.). W artykule będą przywołane niektóre z wypowiedzi uczestników tego ważnego wydarzenia naukowego.

Wobec istniejących już publikacji dotyczących „Zmartwychwstania Rzymu" w niniejszym artykule zostanie podjęta analiza przedstawionych przez Chiarę Lubich treści z punktu widzenia możliwości zastosowania ich do psychopedagogiki specjalnej. Jest to możliwe, gdyż tekst ten, jak i cała duchowość Focolare, będąc głęboko chrześcijański, odnosi się do każdego człowieka niezależnie od poziomu sprawności jego funkcjonowania. Sama Chiara Lubich otrzymała m.in. w 1996 r. Nagrodę UNESCO za Wychowanie dla Pokoju oraz 16 doktoratów honoris causa, w tym z pedagogiki w Catholic University of America w Waszyngtonie, USA, 10 listopada $2000 \mathrm{r}^{10}$ Lubich jest również autorką tekstów o Jezusie wychowawcy oraz związku charyzmatu jedności z pedagogiką i psychologią ${ }^{11}$.

8 „Zmartwychwstanie Rzymu” zostało po raz pierwszy opublikowane w La Via (36/1949) a następnie w czasopiśmie ruchu Focolare Nuova Umanita 6/17 (1995): 5-8. Tekst ten w języku polskim został opublikowany dwukrotnie - w książce Patrzeć na wszystkie kwiaty. Wybór tekstów teologicznych z dwumiesięcznika „Nuova Umanita” (Kraków: Fundacja Mariapoli), 13-19, oraz w książce Chiara Lubich, Charyzmat jedności, red. Michel Vandeleene (Kraków: Fundacja Mariapoli, Wydawnictwo M, 2007), 251-255.

9 Abignente, Przeszłość i teraźniejszość, 279.

${ }^{10}$ Dottorati honoris causa conferiti a Chiara Lubich. Laudationes, Motivazioni, Lezioni magistrali, red. Florence Gillet, Rosalia Parlapiano (Roma: Città Nuova Editrice, 2016), 309-329.

${ }^{11}$ Lubich, Charyzmat jedności, 308-326. 
Ze względu na kluczowy dla pedagogiki problem filozoficzno-antropologicznej koncepcji człowieka jako bazy wyjściowej dla dalszych analiz nad kształceniem i wychowaniem, należy podkreślić, że przyjętą tutaj koncepcją jest personalizm chrześcijański. Swoim szerokim, integralnym spojrzeniem na człowieka wpisuje się on $\mathrm{w}$ humanistyczną tradycję pedagogiki polskiej, również w tym obszarze, w którym zajmuje się człowiekiem z niepełnosprawnością. Inaczej mówiąc, w tekście zostanie podjęta analiza treści „Zmartwychwstania Rzymu” w kontekście relacji interesujących pedagogikę specjalną inspirowaną personalizmem chrześcijańskim.

\section{Przedmiot refleksji Chiary Lubich w tekście „Zmartwychwstanie Rzymu"}

W tekście „Zmartwychwstanie Rzymu” Chiara Lubich mówi o wielkich sprawach filozoficzno-teologicznych dotyczących każdego człowieka. Przeprowadza refleksję nad kondycją człowieka jako bytu przygodnego, poddanego słabościom, grzechowi i śmierci, nad istotą Boga - Bytu doskonałego i wiekuistego oraz nad ich wzajemną relacją, a nawet głębiej, nad więzią, jaka łączy Byt Nieskończony z bytem skończonym, Życie z marnością podległą śmierci, Światło z ciemnością, Ogień z chrustem, który może on spalić ${ }^{12}$.

Refleksja ta przybrała formę krótkiego poetyckiego traktatu filozoficzno-teologicznego o dramacie człowieka, który przechadza się przez współczesny Rzym i dostrzega rażący kontrast między pełnym brudu i marności miastem oraz panoszącym się w jego domach „wszelkim grzechem” a Ideałem, dla którego dwa tysiące lat temu ludzie byli zdolni nie tylko zbudować tak imponujące budowle, zachwycające do dziś nasze oko, ale również byli gotowi oddać za niego życie ${ }^{13}$. Można szukać różnych środków, aby zaradzić tej przygnębiającej obecnie rzeczywistości, ale będą one drugorzędne wobec najważniejszego, aby pozwolić Bogu na nowo wcielać się w nas i utrzymywać Jego pomiędzy nami. Dostrzeżenie Boga-Miłość w każdym człowieku i utrzymywanie go między braćmi - w tym widzi Chiara Lubich ratunek dla świata i „rozwiązanie każdej ludzkiej i Boskiej sprawy”"14.

Minęły cztery lata od zakończenia gehenny II wojny światowej. Lubich, przebywając w Rzymie zniszczonym kilkudziesięcioma nalotami aliantów,

\footnotetext{
12 Tamże, 251, 252.

13 Tamże, 251.

14 Tamże, 255.
} 
widzi nie tylko zgliszcza, brud, ale też marność tego, co tak łatwo uległo zniszczeniu, i tego, co odbudowywane, a też przemijające. Widzi kontrast pomiędzy miłością wzajemną pierwszych chrześcijan gotowych oddać życie za swój Ideał a panoszącym się obecnie jadem nienawiści, niepokojem i różnego typu grzechem. Przechadzając się ulicami Rzymu, nie wpada jednak w rozpacz, nie daje się ponieść uczuciom żalu, lęku, napięcia czy beznadziei. Przeciwnie. Odrywa wzrok od miasta. Łączy się duchowo z Jezusem, który tak jak ona patrzył na swoje miasto - na Jerozolimę. Widział rozpowszechniający się grzech i czekający ją upadek, odczuwał wzgardę innych, został odrzucony i zabity, a jednak nie uległ zwątpieniu, nie uciekł się do odwetu. Modlił się za miasto, za jego mieszkańców i oddał życie za nich, za wszystkich ludzi jako dzieci Boga, aby mogli być z Nim w wieczności ${ }^{15}$.

Lubich patrzy na Boga, który z miłości stał się człowiekiem i łączy się z Trójcą Świętą zamieszkałą w jej duszy. Pozwala przeniknąć się przez Boga, uczynić siebie drugim Chrystusem, tak aby już nie ona patrzyła na świat, ale aby Chrystus patrzył przez nią na świat. I wtedy widzi ludzkość oczami Boga, a tym samym odkrywa w drugim człowieku Jego samego, Jego - jako Miłość, Ogień, Światło i Życie. Drugi człowiek staje się umiłowanym bratem, w którym żyje Chrystus. W relacjach z drugim patrzenie na niego oczyma Chrystusa budzi w nim życie i miłość ${ }^{16}$. Miłość wzajemna jest tym, co pozwoli wskrzesić piękno i życie Rzymu.

Chiara Lubich w swoim tekście posługuje się językiem charakterystycznym dla mistyka - poetyckim, obrazowym, metaforycznym, pełnym symboli, a jednocześnie prostym, odwołującym się do ludzkiego doświadczenia i percepcji zmysłowej. Przeżycia duchowe opisuje za pomocą określeń z zakresu zmysłu wzroku (oczy, źrenica, wzrok, spojrzenie, mgnienie oka, widzieć, patrzeć, spoglądać, oświecać, zajaśnieć, promieniować, światło, blask, ciemność, widoczne, niewidzący, widomy, zgaszony) oraz zmysłu słuchu (mowa, milczenie, niemi, słuchać, przemawiać, zagłuszane). Odwołuje się do czucia i uczuć (miłość, radość, szczęście, nienawiść, niepokój, smutek, niespełnione pragnienia, czuć, odczuwać, kochać) i zdolności umysłowych (myśleć, rozumieć, wątpić, odkrywać, nieświadomość). W miarę wielokrotnego czytania tego tekstu i wgłębiania się w jego przesłanie można odkrywać coraz to nowe perspektywy rozumienia człowieka i jego odniesienia do Boga.

\footnotetext{
15 Tamże, 251, 252.

16 Tamże, 253.
} 
Natomiast dla wyrażenia istoty Boga Lubich odwołuje się do obrazów Życia (sześć razy), Ognia (sześć razy) i Światła (siedem razy), opisując nimi przymioty Boga, a nawet samą Jego Istotę oraz działanie wobec człowieka. Bóg to Ojciec, Trójca Święta, Bóg-Człowiek, doskonały Człowiek, Światło, Ogień i Prawda, Słowo, Miłość, Życie, pełne Życie, prawdziwy Byt, realne Wszystko, Przedwieczny i Niestworzony, Prawodawca, odwieczny Mistrz, Ten, „Który Jest i Który ma wartość”. Stosowanie przez Lubich tak dużego bogactwa określeń na istotę Boga wskazuje na jej bliską łączność z Nim Bóg jest przez nią poznany, kochany, naśladowany, a ona sama czuje się z Nim zespolona. Aby być jednością z braćmi, najpierw otwiera się na łaskę zjednoczenia z Nim.

\section{Kondycja współczesnego czlowieka i świata}

Pochylając się nad kondycją człowieka, Lubich dokonuje jej opisu z punktu widzenia współczesnego człowieka przechadzającego się po Rzymie. Miasto to symbolizuje świat, ale też człowieka jako takiego. Doświadczenie, którym założycielka Ruchu Focolari dzieli się w swoistym „traktacie", jest uniwersalne. Każdy człowiek w każdej epoce żyje w Rzymie, tzn. w świecie ,pełnym brudu i marności”. Również w sobie odnajduje „Rzym”jako symbol jego realnej kondycji, którą cechuje opanowanie przez „nienawiść, niepokój i wszelki grzech”" Człowiek jest „Rzymem” powołanym do zmartwychwstania. Jednak świat współczesny w szczególnym nasileniu został naznaczony grzechem, odrzuca Boga i depcze godność człowieka.

Doświadczanie świata jako Rzymu chylącego się ku upadkowi jest wspólnym doświadczeniem ludzi wszystkich epok. Natura ludzka - była grzeszna i słaba, co nie zmienia się od czasu wygnania z raju. Człowiek patrzy na świat i widzi w nim tyle zła, że coraz częściej ma ochotę uciec od niego, aby nie widzieć jego marności. Patrząc ze swojej ludzkiej perspektywy, widzi panoszące się zło, wszechobecne, krzykliwe i zwyciężające, niemożliwe do pokonania, zdolne do odwetu wobec tych, którzy chcą z nim walczyć. Konsekwencją wpatrywania się w zło istniejące i coraz bardziej rozpowszechniające się w świecie jest utrata nadziei, brak wiary w siebie, drugiego człowieka i przyszłość świata.

Doświadczanie Rzymu w sobie jest nieustannym, odwiecznym doświadczeniem człowieka. Jednostka idzie przez życie i dostrzega w sobie Rzym -

17 Tamże, 251. 
widzi siebie jako przygodny byt, podatny na choroby, cierpienie i śmierć, swoją skłonność do uganiania się za marnością, swoją słabość prowadzącą do grzechu. Słabości i grzech czynią go brudnym i zniechęconym. Odechciewa się mu żyć jako temu, który jest pokonywany przez zło i śmierć. Człowiek jest Rzymem ,pełnym smutku i niespełnionych pragnień”, ugania się za „nicością, która przemija”, i wszystko zmierza w nim ku upadkowi ${ }^{18}$. Trwa jako nieświadomy, niewiedzący, bezwładny, chromy i niemy, ,pozostający ze zgaszonym wzrokiem", bo w jego duszy panuje ciemność ${ }^{19}$.

Brud grzechu i marność złych przyzwyczajeń spotyka człowiek nie tylko, gdy patrzy na czyny swoje oraz innych, ale też dostrzega je ,jeszcze bardziej w ukryciu domów" ${ }^{20}$, tzn. w ludzkich sercach, w tym, co niewidoczne, jak motywy, pragnienia, aspiracje, intencje, cele działania, dążenia. Tam jest źródło wszelkiego grzechu.

\section{Więź Boga z człowiekiem i człowieka z Bogiem}

Opisano wcześniej, jaki jest człowiek, ale nie jest to cała prawda o nim jako o Rzymie. Człowiek jest stworzeniem o „twardym karku”, a jednak Bóg upomina się o niego. Sam wielokrotnie wkraczał w historię swojego narodu wybranego, np. w czasie wędrówki Izraela przez pustynię do Ziemi Obiecanej. Gdy „nadeszła pełnia czasów” (Ga 4,4), wkroczył w historię ludzkości. A teraz wkracza w życie każdego z nas i idzie przed nami, wskazując drogę, idzie za nami, ochraniając nas od wroga, oraz z nami, pośrodku nas jako nasz Zbawca, a jednocześnie Brat i Przyjaciel. Wyzwaniem dla każdego człowieka jest dostrzec z wdzięcznością obecność Boga, Jego łaski we własnym życiu.

Człowiek, stworzony na podobieństwo Boga, jest wolny i powołany do wolnego i radosnego „Zdobywania Nieba” ${ }^{21}$. Wolność człowieka wynika z podobieństwa do Boga - ma na Jego wzór doświadczać radości tworzenia własnego szczęścia. Człowiek został stworzony do podnoszenia swojego człowieczeństwa na najwyższą miarę, powołany do bycia „wiecznym miastem" Boga. Zrealizowanie tego powołania objawiło się przez życie świętych i męczenników, którzy „,promieniowali wiecznym świattem” i dali

\footnotetext{
18 Tamże, 252.

19 Tamże, 251.

20 Tamże.

21 Tamże.
} 
świadectwo „miłości jednoczącej”22. Dla każdego z nas nie ma innej drogi budowania siebie jako „wiecznego miasta”, jak poprzez starania, aby być świadkiem tej jednoczącej miłości. Nie jest to łatwe zadanie w świecie pełnym podziałów (religijnych, narodowych, rodzinnych), ale Ideał nie jest daleki, jest blisko nas, jest w nas i z Niego możemy czerpać siły do przezwyciężania tego, co „rażąco kontrastuje" ${ }^{23}$ z Nim.

Lubich podaje narzędzie - nie odłączaj się od swego Korzenia i Źródła życia, wejdź w kontakt z Nim, pozwól na stopienie się z Nim, na stawanie się jednością z Nim, przez swoją nicość patrz oczami Boga na siebie, na świat, na Niego. Zrobienie w sobie próżni i stanięcie się przeźroczystym przyciąga Boga-Pełnię, który przywraca człowiekowi życie i obdarza go Miłością. Gdy Chrystus żyje w człowieku, drugi staje się bratem - drugim Chrystusem, a wzajemne relacje są przepełnione miłością, świadectwem miłości Trzech. Taka nadprzyrodzona miłość obfituje życiem, wskrzesza człowieka-Rzym do bycia Wiecznym Miastem Boga i budowania wiecznych ,miasteczek” w Mistycznym Ciele Chrystusa. Jezus, ,najgłębsza osobowość każdego człowie-

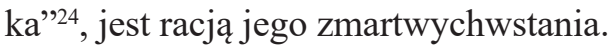

Człowiek, aby nie dać się przytłoczyć i zmiażdżyć przez Rzym, jaki spotyka w sobie i wokół siebie, musi oderwać się od skoncentrowania na sobie, na złu, które panoszy się w świecie, a zwrócić swoje oczy na Pana. Lubich mówi o „wzroku zgaszonym”, który przestaje być takim, jeśli „Moje człowieczeństwo stapia się z tym, co Boskie"25. Lubich używa 10 razy słowa „patrzeć”, w tym cztery razy sformułowania „patrzy Chrystus”, trzy razy odnosi się ono do niej, a dwa razy pisze, że patrzy oczami Chrystusa: „Ale patrzę już nie ja, lecz patrzy we mnie Chrystus" ${ }^{26}$. Podobnie używa słowa „widzę”. Najpierw zaznacza ona, że człowiek może zachowywać się jak „niewidzący”, jeśli nie widzi „Boga w sobie i wokół siebie”. Wtedy widok Rzymu może przyprawić go o zniechęcenie, wywołać lęk zagubienia Ideału. Przywrócenie wzroku, jakim „Jezus patrzył na taki świat”, jest możliwe, jeśli postaram się patrzeć Jego oczami. Wtedy, gdy „patrzy we mnie Chrystus”, to „On widzi na nowo" 27 . Wtedy i ja „Widzę i odkrywam w drugich to samo Światło, które jest we mnie, moją prawdziwą Rzeczywistość, moje prawdzi-

\footnotetext{
22 Tamże.

23 Tamże.

${ }^{24}$ Tamże, 255, przyp. 186.

25 Tamże, 252.

26 Tamże.

27 Tamże.
} 
we «ja» w drugich"28. Ratunkiem dla człowieka jest więc patrzenie na Pana i poprzez zjednoczenie z Nim patrzenie na świat i siebie, na swoje wnętrze Jego oczyma, widzieć siebie tak jak On widzi, kochać siebie tak jak on kocha. Inaczej mówiąc - kochać dziecko Boże w sobie.

\section{Rzeczywistość niepełnosprawności - „Rzym" budzący postawy negatywne}

We współczesnym świecie głośna stała się idea integracji oraz inkluzji osób z niepełnosprawnością do społeczeństwa. Nie byłaby ona potrzebna, gdyby osoby z niepełnosprawnością były w społeczeństwie traktowane z należnym im szacunkiem, gdyby były przestrzegane ich prawa i zaspokajane ich potrzeby, gdyby były włączone w nurt życia środowiska rodzinnego, sąsiedzkiego, lokalnego, w tym religijnego tam, gdzie żyją. Niestety, spotykamy się z dużą rozbieżnością między deklarowanymi wobec nich postawami, które są generalnie pozytywne, a postawami przejawianymi w codzienności, zwłaszcza wobec niektórych grup, jak np. osoby chore psychicznie, ciężko i przewlekle chore, osoby z niepełnosprawnością sprzężoną (wieloraką), osoby w podeszłym wieku i dzieci, wobec których postawiono niepomyślną diagnozę prenatalną. Publicznie wyrażane stanowiska stoją nieraz w rażącej sprzeczności z prywatnym, faktycznie prezentowanym podejściem.

W kontakcie z osobami z niepełnosprawnością rodzą się czasem podobne odczucia do tych, jakie miała Chiara Lubich, patrząc na powojenny Rzym. Jej doświadczenia w kontakcie ze zniszczonym pożogą wojenną miastem mogą być inspiracją do przemyśleń nad rzeczywistością niepełnosprawności w dzisiejszym świecie oraz podkreślenia ważnych z punktu widzenia pedagogiki chrześcijańskiej kwestii.

Pierwszym odczuciem, jakie zrodziło się w Chiarze Lubich na widok Rzymu oraz jakie pojawia się w nas w kontakcie z osobą z niepełnosprawnością, jest dostrzeganie rażącego kontrastu między tym, jak powinno być, a rzeczywistym stanem rzeczy. Poczucie kontrastu można pogłębiać, jeśli będzie się zwracać uwagę na różnice, koncentrować na tym, co utracone, zniszczone, co nie spełnia normy, nie mieści się w kanonie piękności, odbiega od standardu sprawnego funkcjonowania. Uwypuklanie różnic powoduje poczucie obcości, ,bycia z innej bajki”, niemożności porozumienia się, skłania do zachowania ostrożności w kontakcie, do oficjalnego i pozbawionego

28 Tamże, 253. 
emocji stosunku do kogoś. Co może zmienić ten destrukcyjny sposób patrzenia na drugą osobę? Lubich podejmuje decyzję, aby nie patrzeć dalej na Rzym takim ,zgaszonym wzrokiem” i wtedy w jej duszy przestaje panować ciemność. Patrzy na Rzymian jak na siebie, jako na dzieci jednego Ojca, których On chce zjednoczyć ze sobą ${ }^{29}$. Jest to bardzo istotna podpowiedź dla nas, w jakim kierunku powinna zmierzać zmiana postawy wobec osób $\mathrm{z}$ niepełnosprawnością. Zmianę tę umożliwi patrzenie na te osoby nie przez pryzmat dzielących nas różnic, ale przez pryzmat podobieństwa - wszyscy zostaliśmy stworzeni na obraz i podobieństwo Boga i jesteśmy dziećmi jednego Ojca; każdy z nas jest „bardziej dzieckiem Boga [...] niż dzieckiem

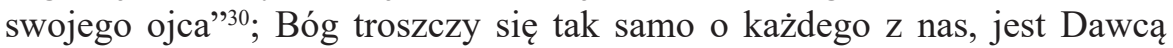
„wszelkiego dobra dla wszystkich dzieci bez różnicy - jak Ojciec ${ }^{31}$ ”; wszyscy mamy szansę ,życia przez całą Wieczność jako dzieci Boga”; wszyscy jesteśmy obdarzeni wolną wolą i na ile to możliwe, możemy „być twórcami własnego szczęścia" ${ }^{2}$.

Patrzenie na osobę z niepełnosprawnością w aspekcie wspólnego nam dziecięctwa Bożego pozwala dostrzec jej podmiotowość, wartość i godność osobową, której żaden typ niepełnosprawności nie może ani odebrać, ani naruszyć. Niepełnosprawność może zaburzyć sferę zmysłową, ruchową, intelektualną, psychiczną, ale nie zakłóca struktury osobowej bytu ludzkiego. Bez względu na rozmiar lub stopień ograniczenia sfer funkcjonowania człowieka ontycznie jest on zawsze osobą z przynależnymi mu bezwzględnie prawami ludzkimi. Ułomność nie niszczy w sposób istotny bytowej struktury człowieka, a jedynie pewne wymiary jego funkcjonowania, nie sięga głębi bytu osobowego, ale ukazuje brakowość jako immanentną cechę człowieka wynikającą z jego przygodności i decydującą o zmiennej funkcjonalności bytu ludzkiego. Nie da się być bytowo niepełnosprawnym, gdyż naruszenie istoty bytu człowieka spowodowałoby jego unicestwienie ${ }^{33}$. Spojrzenie na człowieka z punktu widzenia ogólnej teorii bytu i personalizmu chrześcijańskiego, który prezentowała założycielka Ruchu Focolari, pozwala uratować „człowieka w człowieku”.

29 Tamże, 251.

30 Tamże, 255.

31 Tamże, 253.

32 Tamże, 252.

33 Wojciech Chudy, „Sens filozoficzny kondycji człowieka niepełnosprawnego”, w: Osoba niepetnosprawna i jej miejsce w społeczeństwie, red. Dorota Kornas-Biela (Lublin: Redakcja Wydawnictw KUL, 1988), 105-122. 
Kroczenie po zniszczonym wojną Rzymie prowadzi Chiarę Lubich do refleksji nad przemijalnością, skończonością i kruchością tego, co istnieje. Jej odpowiedzią nie jest jednak porzucenie Ideału, uznanie ważnych wartości życiowych za utopię, popadnięcie w depresję i beznadzieję. Przeciwnie wie, że nie może odłączyć się od Tego, który jest „korzeniem stworzenia i Życiem wszystkiego"34. Scala się więc w jedno z Trójcą Świętą i uzyskuje inną optykę w patrzeniu na świat i drugiego człowieka. Podobnie w kontakcie z osobą niepełnosprawną każdy człowiek ma szansę dostrzec przygodność bytu ludzkiego, a więc i swojego. Przygodność jest kategorią metafizyczną wskazującą na niesamowystarczalność egzystencjalną człowieka, niekonieczność jego istnienia, kruchość i skończoność życia. Osoba z niepełnosprawnością jest dla wszystkich „znakiem przygodności”, swoistym memento mori, tzn. ze względu na swoje trudności i ograniczenia uświadamia każdemu człowiekowi przygodność jego istnienia, a tym samym ukierunkowuje go ku wartościom stałym, obiektywnym, absolutnym, ku perspektywie nadprzyrodzonej, ku Bytowi pełnemu, mocnemu i wiecznemu ${ }^{35}$. Poczucie wspólnoty osób pełnosprawnych z niepełnosprawnymi poprzez egzystencjalne doświadczenie przygodności prowadzi do przywarcia do Tego, który Jest, który jest Życiem, pełnym Życiem, i swym życiem obdarza wszystkie swoje dzieci. Pozwala też afirmować życie nawet w najprostszej jego postaci, również wtedy, gdy jest zdeformowane, obciążone wadami, z perspektywą rychłej śmierci ${ }^{36}$.

Koncentracja na marności, niemocy, brudzie i grzechu miasta, jakim jest człowiek, nie pozwala dostrzec prawdziwych potrzeb tych, którzy są jego mieszkańcami jako niewidzący, głusi, niemi, chromi. Patrząc na miasto i świat pełen miernoty i odwracający się od Światła, można się zniechęcić i odwrócić od tych, którzy są naszymi braćmi. Podobnie w kontakcie z osobą z niepełnosprawnością. Skupienie się na brakach, uszkodzeniach, zaburzeniach i upośledzeniu prowadzi do skrzywienia naszej optyki - dostrzegamy tylko część rzeczywistości niepełnosprawności, tylko pewne aspekty tego, co

${ }^{34}$ Lubich, Charyzmat jedności, 252.

35 Wojciech Chudy, „Powołanie osoby niepełnosprawnej w nauczaniu papieża Jana Pawła II", w: Osoba niepetnosprawna i jej miejsce w społeczeństwie, red. Dorota Kornas-Biela (Lublin: Redakcja Wydawnictw KUL, 1988), 123-149.

${ }^{36}$ Dorota Kornas-Biela, „Afirmacja życia w kontekście jego zagrożeń po niepomyślnej diagnozie prenatalnej”, w: Życie i śmierć. Wyzwania działalności charytatywnej, red. Józef Stala (Tarnów, Lublin: Wydawnictwo Polihymnia, 2012), 171-188; Dorota Kornas-Biela, „Hospicjum perinatalne jako forma afirmacji życia”, w: Życie i śmierć. Wyzwania działalności charytatywnej, red. Józef Stala (Tarnów - Lublin: Wydawnictwo Polihymnia, 2012), 201-216. 
stanowi osobę z niepełnosprawnością, tylko te zakresy jej funkcjonowania, które zostały dotknięte przez chorobę lub niepełnosprawność. Wtedy osoba ta jest odbierana jako ktoś inny i gorszy, a to rodzi lęk, poczucie niezrozumienia i niemożności komunikacji, dystans (unikanie, nieangażowanie się), pragnienie ucieczki od kontaktu lub chęć skrócenia go do koniecznego minimum, deprecjonowanie (dewaluację), delegitymizację (utrwalanie negatywnych ocen, zwyczajów) i uchwalanie przepisów prawnych, które utrudniają pełny dostęp do usług i możliwości leczenia się, rehabilitacji, edukacji, pracy zawodowej i rozwoju osobistego ${ }^{37}$. Idąc śladami Lubich, należałoby spojrzeć na osobę z niepełnosprawnością tak, jak widzi ją Chrystus. Wtedy „widzę i odkrywam w drugich to samo Światło, które jest we mnie"38. Wtedy jest możliwość doświadczenia nie tylko wspólnoty egzystencjalnej, tej samej dla każdego kondycji ludzkiej, ale też dostrzeżenia wartości przyrodzonej i nadprzyrodzonej osoby z niepełnosprawnością, jej powołania w świecie ${ }^{39}$, jej miejsca we wzajemnych odniesieniach, kiedy Chrystus pomiędzy nami zajmuje pozycję Trzeciego i czyni z nas jedno - jej roli w budowaniu komórek Mistycznego Ciała Chrystusa ${ }^{40}$.

Chiara Lubich, poprzez pozwolenie Bogu, by żył w niej, wypełnił ją całym Niebem, uzyskuje spojrzenie na świat i ludzi Chrystusa - ,patrzę już nie ja, lecz patrzy we mnie Chrystus”, „widzę ludzkość oczami Boga”" ${ }^{41}$. W ten sposób nie koncentruje się już na fizycznej niedoskonałości świata, ale zauważa jego duchową ślepotę, głuchotę, bezwład, niemoc mówienia. Czuje przynaglenie, aby przywracać wzrok niewidzącym Boga, słuch tym, którzy nie odbierają Słowa Bożego, moc mówienia do tych i za tych, co są niemi wobec słów Boga, władzę działania chromym wobec poruszeń woli Bożej i aktywnego miłowania. Zwrot, jaki dokonuje Lubich, aby nie koncentrować się na „czystości zewnętrznej strony kubka i misy”, gdyż wtedy nie zauważy się, iż ,wnętrze pełne jest zdzierstwa i niegodziwości” (Łk 11, 39), zachęca do podobnego odwrócenia oczu od zewnętrznych oznak niepełno-

37 Dorota Kornas-Biela, „Niepełnosprawność w rodzinie - czym jest, co znaczy, trudne początki”, w: Rodzina. Bezcenny dar i zadanie, red. Józef Stala, Elżbieta Osewska (Radom: Polskie Wydawnictwo Encyklopedyczne), 643-645.

${ }^{38}$ Lubich, Charyzmat jedności, 253.

39 Dorota Kornas-Biela, „Osoba niepełnosprawna, chora, cierpiąca: nauczanie Jana Pawła II”, w: Rodzina: źródło życia i szkoła miłości, red. Dorota Kornas-Biela (Lublin: Towarzystwo Naukowe KUL, 2000), 357-384.

${ }^{40}$ Lubich, Charyzmat jedności, 253.

${ }^{41}$ Tamże, 252, 253. 
sprawności fizycznej, zmysłowej czy umysłowej i skierowaniu serca w stronę dostrzeżenia chorób duszy, niesprawności w zakresie miłowania, słuchania Słowa Bożego i wypełniania go - u siebie i u innych. Ci zabiegani za sprawami codzienności, nieraz bardzo zamożni, posiadający wysoki status społeczny i uznanie, mogą być bardzo cierpiący na duszy, potrzebujący ratunku, aby nie zatracić się w dobrach tego świata, które „mól i rdza niszczą” i złodzieje kradną (Mt 6,19).

Interesujący wątek w tekście „Zmartwychwstanie Rzymu” dotyczy wolności. Lubich pisze o wolności człowieka w kreowaniu własnego szczęścia oraz osiągania pełni zjednoczenia z Bogiem. Powołuje się przy tym na podobieństwo człowieka do Boga, który „musiał im pozostawić radość wolnego zdobywania Nieba"42. Twórcza wolność, którą człowiek został obdarowany, jest ściśle związana z jego kondycją bytową jako osoby ludzkiej, z jego podmiotowością i godnością. „Osobowa autokreacja jest projektowaniem własnej drogi stawania się dzieckiem bożym, własnego uczestnictwa w Bożej wszechmocy. Wolność człowieka odsłania przed nim potencjał samokształtowania siebie" ${ }^{43}$, a człowiek, rozwijając go, ,może być twórcą własnego szczęścia"44. Niektóre osoby z niepełnosprawnością są ubezwłasnowolnione, tzn. pozbawione sądowo możliwości decydowania o sobie i wykonywania czynności prawnych. Każda osoba pozostaje jednak istotą wolną w sferze ducha niezależnie od stopnia i rozmiaru upośledzenia, gdyż ograniczenia w sferze świadomości i wolności dotyczą jedynie sfery funkcjonalnej. Istotne jest, aby rodzice i profesjonaliści osobom, których zakres świadomości jest ograniczony, pomagali w otwarciu na łaskę, powierzeniu siebie Bogu i życiu w zjednoczeniu z Nim. Zdecydowana większość osób z niepełnosprawnością może w sposób świadomy i wolny odkrywać i wzrastać w swoim człowieczeństwie, pracować nad swoim charakterem, dokonywać wyborów wartości, które czynią człowieka „drugim Chrystusem”, osiągać dojrzałość duchową i ciągle przerastać siebie, doskonalić się.

Każdy profesjonalista pracujący z osobami z niepełnosprawnością oraz z ich rodzinami, a zwłaszcza wychowawca, nauczyciel, pedagog, musi pamiętać, że rzeczywistość niepełnosprawności odnosi się do sfery funkcjonalnej,

42 Tamże, 251.

43 Arkadiusz Wąsiński, , «Zmartwychwstanie Rzymu» - widziane z perspektywy osobowego wymiaru autoformacji i autokreacji człowieka”. Referat, Międzynarodowe Sympozjum Interdyscyplinarne „Doświadczenie Zmartwychwstania Rzymu. Perspektywa filozoficzno-społeczna wobec współczesnego kryzysu kultury”, Wilga-Trzcianka, 15-16.06.2017 r.

${ }^{44}$ Lubich, Charyzmat jedności, 252. 
a nie bytowej, chociaż głębokie upośledzenie i jego konsekwencje utrudniające komunikację, codzienne życie i wykonywanie nawet prostych czynności mogą przysłaniać tę prawdę. Traktowanie niepełnej sprawności w zakresie intelektualnym, zmysłowym czy ruchowym, jak również niepełnosprawności w zakresie ducha jako totalnej - obejmującej całego człowieka, prowadzi do tego, że osoba z niepełnosprawnością zostaje pozbawiona specyficznie ludzkiego pierwiastka, który wyróżnia człowieka ze świata zwierząt - a jest nim duchowość. To „odduchowienie” osób z niepełnosprawnością intelektualną skutkuje tym, że nie są odbierani jako „tacy sami”, równi wobec innych, mający takie same prawa, przeciwnie - jako inni, obcy, gorsi, drugiej kategorii, mniej znaczący. Niedostrzeganie sfery duchowej osób z niepełnosprawnością zwalnia rodziców i wychowawców z konieczności stwarzania dzieciom i młodzieży warunków sprzyjających rozwojowi głęboko ludzkich potrzeb i kompetencji, zwalnia też instytucje z troski o rozwój duchowy swych podopiecznych, będący warunkiem integralnego rozwoju osoby i jej dojrzałości. Niedocenienie sfery duchowej w życiu i wychowaniu osób z niepełnosprawnością pogłębia ich dewaloryzację, stereotypizację i stygmatyzację w społeczeństwie, przyczynia się do utrwalania barier psychicznych i społecznych, jakie istnieją między osobami pełno- i niepełnosprawnymi. Trudno wtedy oczekiwać, że promowana integracja oraz inkluzja znajdzie swoje pełne urzeczywistnienie.

Kolejnym zawartym w analizowanym tekście wątkiem tematycznym jest sprawa nadziei. Lubich napisała: „Otwierając w ten nowy sposób oczy na świat zewnętrzny, widzę ludzkość oczami Boga, który wszystkiemu wierzy, ponieważ jest Miłością" ${ }^{45}$. Bóg wierzy w każdego człowieka, w dobro tkwiące w nim, w jego dążenie, by kochać i być kochanym, gdyż został stworzony na Jego obraz i podobieństwo, a więc został powołany z miłości i do miłości. Ta nadzieja Boga jest źródłem wytryskującym w człowieku ku solidarności i miłości osób z niepełnosprawnością. Ożywieni tym duchem nadziei, rodzice, bliscy, profesjonaliści stają się radosnymi świadkami Ewangelii nadziei. Nie koncentrują się na brakach, niedoskonałościach, uszkodzeniu, upośledzeniu, niesprawności, ale na tym, co pozostało, co zdrowe, podatne na rozwój, leczenie i rehabilitację, na tzw. rezerwach fizycznych, psychicznych i duchowych, patrząc $\mathrm{z}$ ufnością w przyszłość, pomimo przeciwności losu. Ewangeliczna nadzieja nadaje sens życiu, które jest skupione na tym, by „być”, a nie na tym, by „mieć”. Gdy coś się nie powiedzie w procesie

45 Tamże, 253. 
edukacji, wychowania lub rehabilitacji, nie ziści się pragnienie osoby z niepełnosprawnością, nie widać postępu w jej rozwoju, nadzieja chroni przed rozpaczą, beznadziejnością, motywuje do urealnienia oczekiwań i szukania innych wyjść z sytuacji. I wtedy w szczególnym stopniu uwidoczniona jest rola innych osób, którzy dostarczają na różne sposoby wsparcia. Sprawdzają się wtedy słowa Dantego Alighieri, że ,nadzieja przychodzi wraz z drugim człowiekiem". Obecności drugiej osoby nic nie jest w stanie zastąpić. Wraz z nią przychodzi Bóg ze swoją niezniszczalną nadzieją.

W procesie kształcenia i wychowania osób z niepełnosprawnością bardzo łatwo o syndrom wypalenia zawodowego. Wtedy profesjonalista doświadcza podobnych uczuć jak Lubich, gdy patrzyła na zniszczony wojną Rzym. Wydaje się, że Ideał jest utopią, bo przyjęte plany, cele i ideały wychowawcze są nie do zrealizowania, wszystko stracone. Można czuć się powalonym brakiem sukcesów, zniechęconym, rozgoryczonym, załamanym. Ale poza obszarem uczuć jest sfera woli i decyzji. Podobnie jak Chrystus, którego współcześni Mu odrzucili, i wydawało się, że został pokonany, zwyciężony przez zło ${ }^{46}$, tak i nauczyciel/wychowawca nie może dać się zniechęcić. Nie może wątpić w realność Ideału, w dobro tkwiące w drugim człowieku, w jego powołanie do szczęścia wiecznego, w wyzwanie do kochania obecnego w nim Jezusa Opuszczonego ${ }^{47}$. Naśladując Jezusa w Jego więzi z Ojcem, wierzy, że nie jest opuszczony, chociaż w codzienności życia może nieraz czuć się przegrany, zrezygnowany i przygnębiony. Poza tym wychowawca musi zdawać sobie sprawę, że wszelkie ideały i cele są dalekie. Jedynie Jezus jest bliski. Wychowawca jest powołany, aby przybliżyć Go wychowankowi. Może to się dokonać, gdy przyjmie drugiego, otworzy się na niego, ukaże mu życiem Boga-Miłość, będzie Jego świadkiem, będzie drugim Chrystusem. Wtedy wychowanek będzie mógł powiedzieć: mój Ideał to nie utopia ${ }^{48}$.

I jeszcze jedna kwestia - Lubich nie odbudowała Rzymu, nie oczyściła go z brudu i nikczemności, ale zmieniła swoje doświadczenie z nim związane dzięki temu, że spojrzała na niego oczyma Boga. Podobnie rodzic, nauczyciel czy wychowawca nie jest w stanie usunąć z życia osoby jej niepełnosprawności czy przewlekłej choroby, ale może zmienić swój stosunek do niej, a tym samym również jej spojrzenie na siebie. Zmiana ta jest możliwa

46 Tamże, 251.

47 Chiara Lubich, Jezus Opuszczony, red. Hubertusa Blaumeisera (Łąka: Indygo i Fundacja Mariapoli, 2017); Chiara Lubich, Krzyk Opuszczenia (Kraków: Wydawnictwo M, 2001).

${ }^{48}$ Por. Lubich, Charyzmat jedności, 251. 
dzięki miłości zakotwiczonej w Bogu. Chiara Lubich w innym miejscu pisała: „miłość bliźniego jest królewską drogą prowadzącą do Boga. Skoro wszyscy jesteśmy Jego dziećmi, nic nie jest tak drogie Jego sercu jak miłość braterska. Nie możemy Mu sprawić większej radości od tej, kiedy kochamy naszych braci” ${ }^{49}$, zwłaszcza tych, którzy są spychani na margines, deprecjonowani, odrzucani. Człowiek chory lub niepełnosprawny to bliźni z przypowieści o Samarytaninie ( Łk 10,30-37). Z nim utożsamia się Chrystus, stąd zostajemy powołani, aby objawiać cierpiącemu Chrystusa, który pochyla się nad nim, wzrusza głęboko, opatruje i pielęgnuje. Bóg powierza nas sobie wzajemnie. Jesteśmy za siebie odpowiedzialni i zobowiązani, aby dawać bliźniemu to, co Bóg dla niego przeznaczył, a nam powierzył, aby ukazywać mu czułości i tkliwość samego Boga. Działania podejmowane na rzecz braci w potrzebie są miarą naszej miłości do Boga i posługą Jemu wyświadczoną. Niesienie żywego Boga innym i bycie Jego odbiciem w świecie jest szlachetną posługą bliską posłudze kapłańskiej ${ }^{50}$. Dzięki szczególnej identyfikacji Jezusa z człowiekiem słabym, chorym, niepełnosprawnym (,Wszystko, co uczyniliście jednemu z tych braci moich najmniejszych, Mnieście uczynili” [Mt 25,40]) w Dzień Sądu ci, którzy czynili miłosierdzie (np. „byłem chory, a odwiedziliście Mnie” [Mt 25,36]), będą nazwani „błogosławionymi Ojca" i wezmą w posiadanie Królestwo (Mt 25,34).

\section{Zakończenie}

W konkluzji przeprowadzonych analiz należy podkreślić, że tekst „Zmartwychwstanie Rzymu" w sposób szczególny odnosi się do wzajemnych relacji między osobami pełnosprawnymi i osobami z niepełnosprawnością. Ukazuje konieczność budowania nowego humanizmu, w którym człowiek jako drugi Chrystus będzie stanowił centrum. Wtedy nie będzie już rozróżniania między nimi ze względu na poziom sprawności, każdy zostanie uszanowany jako osoba zasługująca na prawo do życia, bezwzględny szacunek i miłość.

W „Zmartwychwstaniu Rzymu” Chiara Lubich podkreśla, że Chrystus nie może być tylko krucyfiksem powieszonym na ścianie i spełniającym rolę amuletu, ale musi być żywy w nas. Trzeba pozwolić Mu „,̇yć w sobie, ży-

${ }^{49}$ Chiara Lubich i chrześcijanie z różnych krajów, Pisać Ewangelię życiem (Kraków: Fundacja Mariapoli”, 1998), 96.

${ }^{50}$ Kornas-Biela, „Osoba niepełnosprawna”, 377-379. 
jąc w drugich, bo życie jest miłością - a kiedy miłość nie krąży, umiera"51. Chrześcijanin nie ma więc wyjścia - musi dostrzec w każdym człowieku Chrystusa i miłować Go w nim, pozwalając Mu miłować siebie. Nie tyle mówić o tym, że Bóg jest Miłością, ale być Miłością, być dla drugiego Jezusem. Wprowadzając Jezusa w rzeczywistość Wiecznego Miasta, a więc wszędzie tam, gdzie jest zło, słabość, niedoskonałość, chrześcijanin wskrzesza to miasto do życia, przywraca życie martwym - dzieciom Ojca, a Ojcu dzieci. On zaś, który ,jest Życiem, pełnym Życiem”, obdarza życiem, odnawia przez Ducha, buduje mosty, toruje drogę $e^{52}$. Analizowany tekst Chiara Lubich kończy słowami: „Wystarczy Go kochać”. Podobnie pisała przed laty: „Świętość przychodzi jako konsekwencja miłości. A my możemy ją osiągnąć jedynie w ten sposób. Gdybyśmy chcieli szukać świętości dla niej samej, nigdy jej nie osiągniemy. A więc kochać i nic innego. Stracić wszystko, również przywiązanie do świętości, aby starać się tylko kochać!"53.

\section{Bibliografia}

Abignente, Lucia, Dorota Kornas-Biela, Mariola Teresa Kozubek. „Pedagogiczne inspiracje Ruchu Focolari. W kierunku pedagogiki jedności”. W: Wychowanie chrześcijańskie. Między tradycją a wspótczesnościa, red. Alina Rynio, 1006-1026. Lublin: Wydawnictwo KUL, 2007.

Abignente, Lucia. Przeszlość i teraźniejszość - historia jedności. Studium o duchowości Ruchu Focolarii. Lublin: Towarzystwo Naukowe KUL JPII, 2010.

Bugała, Agnieszka. „Chiara Lubich - świętość to konsekwencja miłości”. Niedziela Ogólnopolska 11 (2015): 16-19.

Chudy, Wojciech. „Powołanie osoby niepełnosprawnej w nauczaniu papieża Jana Pawła II". W: Osoba niepetnosprawna i jej miejsce w spoleczeństwie, red. Dorota Kornas-Biela, 123-149. Lublin: Redakcja Wydawnictw KUL, 1988.

Chudy, Wojciech. „Sens filozoficzny kondycji człowieka niepełnosprawnego”. W: Osoba niepelnosprawna i jej miejsce w spoleczeństwie, red. Dorota Kornas-Biela, 105-122. Lublin: Redakcja Wydawnictw KUL, 1988.

${ }^{51}$ Lubich, Charyzmat jedności, 254.

52 Tamże, 255.

${ }^{53}$ Agnieszka Bugała, „Chiara Lubich - świętość to konsekwencja miłości”, Niedziela Ogólnopolska 11 (2015): 16-19. 
Dottorati honoris causa conferiti a Chiara Lubich. Laudationes, Motivazioni, Lezioni magistrali, red. Florence Gillet, Rosalia Parlapiano, 309-329. Rome: Città Nuova Editrice, 2016.

Grochmal, Stanisław. Paradygmat jedności w kontekście zarządzania organizacjami. Rzeszów: Wydawnictwo Uniwersytetu Rzeszowskiego, 2013.

Kornas-Biela, Dorota. ,The Paradigm of Unity in Prenatal Education and Pedagogy". Journal for Perspectives of Economic Political and Social Integration 1-2/19 (2014): 193-206. DOI: 10.2478/v10241-012-0017-3.

Kornas-Biela, Dorota. „Afirmacja życia w kontekście jego zagrożeń po niepomyślnej diagnozie prenatalnej". W: Życie i śmierć. Wyzwania działalności charytatywnej, red. Józef Stala, 171-188. Tarnów-Lublin: Wydawnictwo Polihymnia, 2012.

Kornas-Biela, Dorota. „Hospicjum perinatalne jako forma afirmacji życia”. W: $\dot{Z} y$ cie i śmierć. Wyzwania działalności charytatywnej, red. Józef Stala, 201-216. Tarnów, Lublin: Wydawnictwo Polihymnia, 2012.

Kornas-Biela, Dorota. „Niepełnosprawność w rodzinie - czym jest, co znaczy, trudne początki”. W: Rodzina. Bezcenny dar i zadanie, red. Józef Stala, Elżbieta Osewska, 638-683. Radom: Polskie Wydawnictwo Encyklopedyczne, 2006.

Kornas-Biela, Dorota. „Osoba niepełnosprawna, chora, cierpiąca: nauczanie Jana Pawła II". W: Rodzina: źródło życia i szkoła miłości, red. Dorota Kornas-Biela, 357-384. Lublin: Towarzystwo Naukowe KUL, 2000.

Kozubek, Mariola Teresa, Stanisław Grochmal. „Rodzina wspólnotą miłości w świetle pedagogii jedności Ruchu Focolari”. W: Wokół rodziny. Wychowanie, kultura, społeczeństwo, red. Andrzej Garbarz, Grzegorz Grzybek, 255-273. Rzeszów: Wydawnictwo i Drukarnia Diecezji Rzeszowskiej, 2011.

Kozubek, Mariola Teresa. „Środowisko wychowawcze rodziny i Ruchu Focolari w doświadczeniu choroby bł. Chiary Luce Badano (1971-1990)". W: Cierpienie - tajemnica i wyzwanie, red. Antoni Bartoszek, 142-160. Katowice: Emanuel, 2014.

Kozubek, Mariola Teresa. „Wspólnota dzieci i młodzieży Ruchu Focolari miejscem kształtowania umiejętności pokonywania trudności”. Roczniki Pedagogiczne 3 (2018): 57-73.

Kozubek, Mariola Teresa. „Wspólnota i jedność w wybranych obszarach życia społecznego - doświadczenie Ruchu Focolari”. Paedagogia Christiana 2/36 (2015): 79-108.

Kozubek, Mariola Teresa. „Wychowanie do przebaczenia w pedagogii jedności”. Paedagogia Christiana 2/38 (2016): 107-126.

Kozubek, Mariola Teresa. „Wychowanie do wiary w rodzinie - propozycja duchowości jedności”. Homo Dei 1 (2014): 23-36. 
Lubich, Chiara i chrześcijanie z różnych krajów. Pisać Ewangelię życiem. Kraków: Fundacja Mariapoli, 1998.

Lubich, Chiara. „Zmartwychwstanie Rzymu”. W: Charyzmat jedności, red. Michel Vandeleene, 251-255. Kraków: Mariapoli Foundation, Wydawnictwo M, 2007.

Lubich, Chiara. „Zmartwychwstanie Rzymu”. W: Patrzeć na wszystkie kwiaty. Wybór tekstów teologicznych z dwumiesięcznika „Nuova Umanità ”, 13-19. Kraków: Fundacja Mariapoli, 2007.

Lubich, Chiara. Jezus Opuszczony, red. Hubertus Blaumeiser. Łąka: Indygo and the Mariapoli Foundation, 2017.

Lubich, Chiara. Krzyk Opuszczenia. Kraków: Wydawnictwo M, 2001.

Olbrycht, Katarzyna. „Co może odnaleźć pedagog w zbiorze tekstów «Charyzmat jedności» Chiary Lubich”. Nowe Miasto 2-3 (2008): 168.

Przygoda jedności: z zalożycielka Ruchu Focolari rozmawia Franka Zambonini. Kraków: WAM, 1995.

Szewieczek, Mirosław. Bijące serce jedności. Bielsko-Biała: Wydawnictwo AKANT, 2003.

Torno, Armando. Chiara Lubich. Życie i dzieto. Poznań: Księgarnia św. Wojciecha, 2012. 